\title{
Motion-and-Song-Based Warm-Up Model for Children with Visual Impairment
}

\author{
Hendrik Kusworo \\ Master Program in Sport Science \\ Yogyakarta State University \\ Yogyakarta, Indonesia \\ Hendrixkoesworo@gmail.com
}

\author{
Sri Winarni \\ Faculty of Sport Science \\ Yogyakarta State University \\ Yogyakarta, Indonesia \\ sri_winarni@uny.ac.id
}

\begin{abstract}
- the aim of this research is to develop a warm-up model that can teach students with visual impairment the motion of warm-up using the media by giving examples via CDs and guide books to teachers in special schools. To achieve this objective, the research was conducted using the Research and Development, with ADDIE model. It consisted of 4 stages: (1) Analysis, (2) Design, (3) Development \& Implementation, and (4) Evaluation. From the results, this study shows that the motion-and-song-based warm-up model for children with visual impairment was declared feasible as a warm-up model for children with visual impairment in special schools. This was backed up by the feasibility result tests obtained from some validators with average scores of 4.2 with an "Excellent" category from a materials expert; 4.75 with an "Excellent" category from a media expert; 4.0 with a "Good" category from a practitioner; and 4.24 with an "Excellent" category from a try-out test.
\end{abstract}

Keywords—warm-up, motion, song, children

\section{INTRODUCTION}

Education is an essential need of humans to ensure a more dignified survival. Hence, every state has an obligation to provide quality education to every citizen without exception, including those with special needs. Citizens who have special needs physically, emotionally, mentally, and / or socially are entitled to special education [1]. This also applies to sport activities, especially in the warm-up activities. As a result of students' visual limitation, the teachers in special schools usually only provide warm-up by walking them round the holding hands or holding the shoulders of friends with assistance from teachers. However, these children are bored by the monotony in every exercise [2]. If in the beginning of a lesson the child is not interested, the activity will not run well because their motivation will decrease. Based on this fact, the researcher created warm-ups that provides comfort, fun, joy, and enhances the motivation during warm-ups before carrying out the main sporting activities or physical activities. The warm-up is a product of motion and songs based on the warm-up model.

\section{METHODS}

This research was conducted using the Research and Development, with ADDIE development model consisting of 4 phases: (1) Analysis, (2) Design, (3) Development \& Implementation, and (4) Evaluation [3]. The subject of this research was the special school students in Yogyakarta, Indonesia with an age range of 7-12 year old consisting of 4 male students and a female student. The sampling was done based on some consideration. Data collection techniques employed in this research were: material feasibility test, media feasibility test, and try-out test on a small scale. To interpret the values, the existing data was converted into 5 constraints of assessment norms that provide assessment into five categories. These categories include [4];

TABLE I. THE CONVERSION GUIDELINE OF QUANTITATIVE TO QUALITATIVE DATA

\begin{tabular}{|c|c|c|}
\hline Score Average & Classification & Conclusion \\
\hline$>4,2$ & Excellent & Can be used as for model \\
\hline$>3,4-4,2$ & Good & $\begin{array}{c}\text { Can be used without } \\
\text { modification }\end{array}$ \\
\hline$>2,6-3,4$ & Enough & $\begin{array}{c}\text { Can be used with minor } \\
\text { modification }\end{array}$ \\
\hline$>1,8-2,6$ & Insufficient & $\begin{array}{c}\text { Can be used with major } \\
\text { modification }\end{array}$ \\
\hline$>1,8$ & Very insufficient & Cannot be used \\
\hline
\end{tabular}

\section{RESULT AND DISCUSSION}

\section{A. Results of Materials Expert Validation}

Materials validation was carried out in two stages. The first stage was conducted in the faculty room of PJKR (Physical Education Health and Recreation) of the Faculty of Sport Sciences in Yogyakarta State University. The materials directly evaluated (the motion and song based warm-up model for children with visual impairment) based on the improved existing criteria. The product obtained a score of 31 with an average of 3.1 . Based on the quantitative to qualitative data conversion guidelines, the developed model fell into an 'enough' category. It needed some revision to improve, considering not all components were achieved optimally. There were several suggestions given by the materials expert such as follows: a) each movement should include counting, b) the image should be adjusted to the description, and c) the movements should be sorted. Based on these suggestions, the product was then revised. After completing the revision, it proceeded with the second stage validation. The result showed that it obtained a score of 42 with an average of 4.2 . Based on the quantitative to qualitative data conversion guidelines, the developed model came in under the very good criteria. To provide a clearer picture related with the assessment results in the first and second stage, a diagram is presented below: 


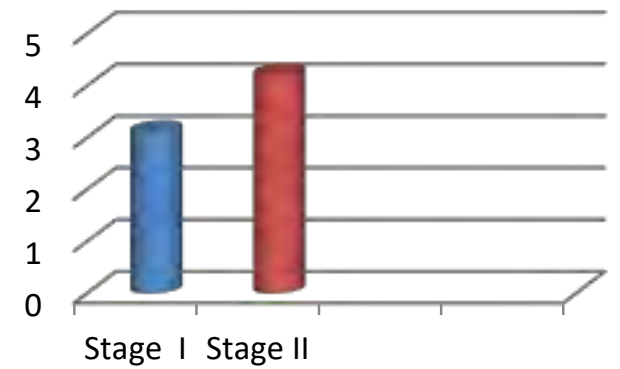

Fig. 1. Results of a Materials Expert Validation

\section{B. Result of Media Expert Validation}

The media validation was conducted in one stage in the faculty room of POR (Sport Education), Faculty of Sport Science, Yogyakarta State University. The result of the assessment of the media expert was a score of 57 with an average of 4.75 . Based on the conversion guideline, the model fell into the excellent category.

\section{Result of a Practitioner of Teaching and Learning's Evaluation}

After being declared as qualified by the material and media experts, this model was tested on a teacher or practitioner in special schools in Yogyakarta. An assessment was done once and displayed a score of 80 with an average of 4.0. Based on the conversion guideline, the developed product fell into the good category.

\section{Result of a Try-out Test}

The final step of the research was the try-out test. Respondents in the test were 5 students, consisting of 4 male students and a female student. It was conducted after all the students were ready. The trial was done for $2 \times 35$ minutes. After the trials, the students were taken to the class to fill out an evaluation in form of a questionnaire to assess the warmup model with assistance from the researcher. The result was a score of 42.4 with an average of 4.24. Based on the conversion guideline, it was categorized under the excellent class.

\section{DISCUSSION}

The development of the motion-and-song-based warm-up model for children with visual impairment was based on the problem of monotony of the warm-up in special as discovered by the researcher, and sometimes, the teacher did not even conduct the warm up at all. If such things continue, it will be fatal for their condition. Warm-ups are very important to be carried out before physical activities. Warmups are also one of the basic parts of the conditioning program [5]. In addition, the success or failure of an activity based on the warm-ups or the beginning [6]. In fact, injuries, pains, and aches are often occur in sports conducted no warm-up at the beginning [7].

The reasons above inspired the researcher to provide solutions by developing the motion-and-song-based warm- up model for children with visual impairment. The model is a kind of warm-up that starts from the stretching the shoulders, hip, knees, and ankles. Stretching is a form of rehearsal exercise which is an element of flexibility which can be in form of: stretching, suppleness, and relaxation [8].

The motion-and-song-based warm-up model for children with visual impairment was developed using the ADDIE development model developed by Gall \& Borg. The ADDIE model consists of 4 main phases: (1) Analysis, (2) Design, (3) Development \& Implementation, and (4) Evaluation.

The first phase was the analysis, this phase aimed to search for data and needs of the research subjects. To get more accurate data, interviews were conducted with sports teachers in special schools for type A-students in Yogyakarta, Indonesia. The results of these interviews served as a starting point for the problems faced by the teacher and students in school. In addition, interviews were carried out with the students. From theses, strengthening arguments were found. The students themselves felt that the previous warmup was monotonous and did not interest them. Thus, it affected the main activity and the motivation of the students. However, a direct analysis of the students' need was also carried out to really ascertain what should be done.

The second phase was the design. After data collection from the analysis, the next step was creating the design of the model. It was developed based on the students' need. Hence, it was designed to be interesting, fun, safe, and also motivate them to join the follow up activity. The warm-up was designed in the form of gymnastics prior to the main sport activity. The reason for this was because it was an appropriate and interesting learning media to train children's psychomotor [9].

Children with visual impairment are children with improper eyesight function. Thus, for them, the teacher must adapt to the children's condition [10]. So, the existing gymnastics motions in this model must adjust to the students' state and condition. The first thing to do was to determine the songs and motions. The selected songs are exciting songs to motivate the body. In addition, the selected songs should also be familiar to the students' ears to avoid confusion when they first listen to it and to be able to follow it easily. In this model, three Indonesian songs were used which were; Bermain Layang-layang, Potong Bebek Angsa, and Menanam Jagung. During the study, lyrics of the three songs were changed into a command movement that would be performed in the warm-up. The purpose of it was to make the students feel at ease during the warm-up. After choosing the songs, the next thing to do was to determine the motions. The motions carried out in this development followed several criteria: a) the motions should make all the students move, b) the students must be able to perform the selected motions, c) the rules given in the warm-up should be made simple, d) the movements of the arms and legs should be varied in order to increase the children's passion, e) the motions should start from the lightweight activity and increased steadily to raise the students' body temperature [8]. 
The next phase was the development \& implementation. At this phase, a material expert conducted validation and a learning practitioner and the students' responses assessed a media expert before it during the try-out. Based on the validation, a score of 4.2 was obtained from a material expert and 4.75 from a media expert both under the "Excellent" categories. Furthermore, based on a practitioner's assessment, a final score of 4.0 under the "good" category was obtained. After obtaining appraisal from the learning practitioner, a try-out was carried out. The final result was a score of 4.24 under the "Excellent" category. Based on the previously mentioned results, it can be concluded that motion-and-song-based warm-up model for children with visual impairment was declared feasible and good as a warm-up model for children with visual impairment.

\section{CONCLUSION}

Based on the discussion above it can be concluded that: The motion-and-song-based warm-up model was declared as a feasible model for warm-up for children with visual impairment in SLBN 1 Bantul. It was supported by the results of feasibility tests obtained from several testers, ranging from an expert of the materials with average score: (4.2) under the "Excellent" category, from a media expert with average score: (4.75) under the "Excellent "category, from a practitioner with average score: (4.0) under the "Good" category, and from a try-out test with average score: $(4,24)$ under the "Excellent" category.

\section{REFERENCES}

[1] Undang-Undang No. 20 Tahun 2003 Tentang Sistem Pendidikan Nasiona.

[2] L. S. Hendi, "Kebosanan Kerja: Peningkatan Stres dan Penurunan Kinerja Karyawan Dalam Spesialisasi Pekerjaan,” Jurnal Jibeka, 2014, vol. 8, pp. 2-8.

[3] B. M. Robert "Instructional Design: The ADDIE Approach". London, University of Georgia, 2009.

[4] Sudiyono, "Pengantar Evaluasi Pendidikan". Jakarta, PT. Grafindo Persada, 2003.

[5] J. M. Alter, "300 Teknik Perengangan Olahraga”. Jakarta, PT. Raja Grafindo Persada, 1996.

[6] Wildan, Irawan "Perbandingan Pengaruh Masase Lokal (Stretching Pasif) Dengan Warming Up (Stretching Aktif) Terhadap Kekuatan Otot Tungkai", Jurnal Kesehatan Olahraga, 2015, vol. 3, no. 2.

[7] Purnono, Pamungkas, "Pengaruh Latihan Gerakan Kaki (Stretching) Terhadap Penurunan Nyeri Sendi Ekstremitas Bawah Pada Lansia Di Posyandu Lansia Sejahtera GBI Setia Bakti Kediri”, Jurnal STIKES RS BABTIS Kediri, 2010, vol. 3, no. 1.

[8] Imam Hidayat,"Senam". Bandung, FPOK-IKIP Bandung, 1996.

[9] N. Trajkovic, "Impact Of Gymnastic Program On Health Related Fitness In Adolescent Pupils", 2016, vol. 8, pp. 157-66.

[10] R. M. Efrina, "Penyelenggaraan Pendidikan Inklusi Bagi Anak Tunanetra Low Vision”, 2014, vol. 3, no. 3, pp. 502-515. 